\title{
Sňatek z rozumu? Výzkum a výuka v pregraduální přípravě učitelů na příkladu kvalitativního výzkumu
}

\author{
Kateřina Lojdová
}

Masarykova univerzita, Pedagogická fakulta, Katedra pedagogiky

Redakci zasláno 11. 8. 2015 / upravená verze obdržena 4. 3. 2016 /

k uveřejnění přijato 5. 3. 2016

\begin{abstract}
Abstrakt: Cílem této kritické studie je představit vztah výzkumu a výuky v pregraduální př́ípravě učitelů na příkladu kvalitativního výzkumu. Studie se skládá ze dvou částí. První část se zabývá historicky a terminologicky vztahem výzkumu a výuky v českém i v zahraničním kontextu. Druhá část se zaměřuje na kvalitativní výzkum v pregraduální přípravě učitelů a pojmenovává benefity i rizika tohoto spojení pro studenty učitelství a vysokoškolské učitele. $V$ závěru shrnujeme efekty spojení výzkumu a výuky pro pedagogickou vědu, autonomii akademikủ a pro učitelskou profesi.
\end{abstract}

Klíčová slova: kvalitativní výzkum, edukace učitelů založená na výzkumu, pregraduální př́prava učitelů, studenti učitelství, výzkum a výuka

Jedním z velkých témat současného pregraduálního vzdělávání učitelů je místo výzkumu na pedagogických fakultách. Živá dlouholetá debata na stránkách pedagogických periodik hovoří jednak o tom, že pedagogický výzkum by měl mít, a může mít, větší dopad na učitelskou praxi (Hargreaves, 1997) a má proto nezastupitelné místo $\mathrm{v}$ př́ípravě budoucích učitelů. Oponenti však kontrují, že pedagogický výzkum nemůže mít takovouto relevanci pro praxi (Hammersley, 1997) a jeho místo na fakultách připravujících učitele zpochybňují. Tvoří výuka a výzkum dva svébytné světy, jejichž propojení se na fakultách odehrává spíše formálně pod tlakem institucionálních požadavků, nebo jsou to oblasti, jejichž provázání může přirozeně přinášet vzájemné benefity? Hledání odpovědi na položenou otázku je věnován tento text.

Cílem textu je nahlédnout na „sňatek výzkumu a výuky“ v zúžené perspektivě. Zaměříme se na kvalitativní výzkum v pregraduální přípravě učitelů, nebot' právě kvalitativní výzkum svou podstatou může přemost'ovat tyto světy. V první části nejprve představíme „dlouhou známost“ výzkumu a výuky skrze 
humboldtovský ideál a jeho naplňování na univerzitách, poté se podíváme na „první rande“ výzkumu a výuky v českém prostředí. V neposlední řadě budeme diskutovat koncepty propojující výzkum a výuku, které ukazují jejich dualitu na základě př́kladů ze zahraniční praxe. Druhá část se zaměřuje již na místo kvalitativního výzkumu na pedagogických fakultách. Pojmenovává profity z tohoto spojení jak pro studenty učitelství, tak i pro vysokoškolské učitele. Ilustrujeme zde „společnou cestu“ výzkumu a výuky akademickým životem včetně překážek, které je na této cestě potkávají. $V$ závěru se zamyslíme nad tím, zda spolu výzkum a výuka zůstanou, „dokud je smrt nerozdělí“, tedy především dokud bude „žít“ pedagogická věda.

\section{1 „Dlouhá známost“: výzkum a výuka od dob Wilhelma Humboldta}

Na první pohled se téma spojení výzkumu a výuky ve vysokoškolském vzdělávání nemusí jevit jako kontroverzní. Přibližně v posledních dvou stech letech jsou totiž univerzity v humboldtovském duchu chápány jako „místa objevování a předávání nového poznání díky společnému působení profesorů a studentů, v nezávislém hledání pravdy a ve svobodném rozvíjení výuky a výzkumu“ (Šima \& Pabian, 2013, s. 11). Výzkum a výuka se tedy „znají" už poměrně dlouho.

Přestože debata o vztahu výzkumu a výuky se vede od dob Wilhelma Humboldta v 19. století (a Humboldt je více či méně oprávněně považován za symbol jednoty výzkumu a výuky), zaměříme se na její podobu v posledních přibližně padesáti letech. Nejprve nahlédneme do zahraničního a poté do domácího prostředí.

Pohled do angloamerického kontextu začneme ve Velké Británii, kde nalezneme balancování nad výzkumem a výukou, které se odehrává v určitém politickém kontextu. Britská vládní zpráva (The Robbins Report) z roku 1963 považuje spojení výzkumu a výuky za distinktivní rys vysokoškolského vzdělávání, který jej odlišuje od jiných stupňů vzdělávání. Avšak o čtyřicet let později vládní zpráva obrací, když se v ní píše, že klíčovou misí univerzit je výuka (Healey \& Jenkins, 2005). Tento obrat byl dle autorů dán změnami ve financování univerzit a nárůstem počtu studentů, protože v této době už studuje na univerzitě $40-50 \%$ populace z věkové kohorty. 
Univerzity a fakulty $v$ různých koutech světa se ve vztahu k výzkumu a výuce diferencovaly. Některé fakulty se orientovaly spíše na výzkum, jiné spíše na výuku. Fakulty můžeme v této optice dichotomicky vymezit jako výzkumné a profesní (či na výuku orientované). Zejména výzkumné fakulty musí řešit, jak spojit výzkum a výuku, přičemž řešení této otázky není jednoznačně dané. $\mathrm{V}$ úvodu slavné americké Boyerovy zprávy pro výzkumné univerzity z roku 1998 se píše: „Doporučení v této zprávě se mohou jevit kontroverzní, některé fakulty proti nim budou protestovat jako proti nedosažitelným a nepraktickým" (Reinventing undergraduate education, 1998, s. 1). Každý na univerzitě má být podle této zprávy objevitel a učící se jedinec. Podstatou výzkumných univerzit je dle zprávy objevování kladením otázek, zjištováním a bádáním ve výzkumných projektech a stejně tak i v kurzech pro studenty.

To, kterým směrem se univerzity a fakulty vydaly, je výrazně definuje. Forest (2002) na základě dat $\mathrm{z}$ výzkumu 20000 fakult po celém světě argumentuje, že mezi fakultami zaměřenými na výzkum a výuku jsou výrazné rozdíly $\mathrm{v}$ hodnocení výuky, podmínek fungování, akademických disciplín, profese a mezinárodní dimenze vzdělávání. Dochází tak $\mathrm{k}$ diverzifikaci institucí v terciárním vzdělávání. Tato diverzifikace však neprobíhá jen mezi institucemi navzájem, ale i uvnitř nich samotných. Evropské univerzity se totiž stávají většími a komplexnějšími (Geschwind \& Broström, 2013). Současné univerzity podle Jongha, Franze a Rhoda (2014) postupně oddělují výzkum a výuku i ve svých strukturách - zakládáním výzkumných center. To přispívá k paradoxu postulování propojení výzkumu a výuky na jedné straně a k vytváření jejich separace v institucionálních podmínkách na straně druhé.

I v Česku se otevřela debata o výzkumných a profesních univerzitách, avšak Šima a Pabian (2013) upozorňují, že strukturální podmínky české vysokoškolské krajiny takovouto diverzifikaci neumožňují - např́íklad z důvodu nízkého počtu vysokých škol oproti americkému modelu. Česká vzdělávací politika však tuto připomínku zcela neakceptovala, nebot' v původních verzích novely vysokoškolského zákona se objevovala diverzifikace vzdělávacích programů na výzkumné, akademické a profesní (Novela zákona o vysokých školách, 2013). K tomuto dělení se kriticky vyjadřuje Štech (2014), který hovoří o trojím dělení vysokých škol jako o klišé. Navozuje se tím totiž představa poměrně jasných hranic - jedni bádají a vzdělávají se výzkumem, další si osvojují poznatky vytvořené jinde a ti poslední se učí praxí zvládnout konkrétní profesi. Avšak existuje i profesionalizační rozměr v oborech akademických a stejně tak badatelské prvky v oborech profesních. Štech (2014) 
zdůrazňuje, že jde spíše o to, zda se student učí dělat vědu (nebo profesi) nebo zda se učí o vědě (nebo o profesi). Tohoto tématu se dotkneme v kapitole 4.1.

Spolu s vývojem univerzit se rozvíjely od 70 . let 20 . století badatelské diskursy, které mezi výzkumem a výukou nacházely pozitivní, negativní či nulový vztah. Ke všem třem typům vztahů jsou hojné publikační výstupy. Šima a Pabian (2013) však upozorňují, že řada těchto výzkumů jsou empiricky nepodložená prohlášení dospívající k banálním tvrzením, například že někdy je propojení pozitivní a jindy ne. Barnett (2005) celou věc označuje za ironickou. Mohli bychom totiž předpokládat, že výzkum vztahu výzkumu a výuky bude na vysoké metodologické úrovni, ale ve skutečnosti tomu tak není. Barnett (2005) pojmenovává mýtus vzájemné prospěšnosti jednoty výzkumu a výuky, který spočívá ve větší síle předpokladu, že mezi výzkumem a výukou je pozitivní vztah, než v síle evidence $\mathrm{k}$ tomuto předpokladu.

S jednotou výzkumu a výuky na univerzitách to tedy není tak jednoznačné, jak se na první pohled může zdát. Pro některé je ideálem, pro jiné prázdnou tezí a pro další dokonce překážkou, kde jedna složka vylučuje druhou. Jeden z posledních kritických hlasů zaznívá od Šimy a Pabiana (2013), kteří tvrdí, že „ideologie hlásající jednotu výzkumu a výuky ve svém působení paradoxně brání jejich smysluplnému propojení: výzkum je v této ideologii totiž důležitější než výuka" (s. 11).

Nepřehlednost může souviset s komplexností problematiky spojení výzkumu $a$ výuky, která sahá od makroroviny neoliberálních politik až po mikrorovinu managementu univerzity, fakulty či katedry, od př́rodovědných přes humanitní po umělecké obory, od základního výzkumu po výzkum aplikovaný. Neporozumění také přispívá nejasné vymezení vědy a výzkumu v některých publikacích a jejich nekriticky a ad hoc přijímaný pozitivní či negativní vztah, který je navíc hledán pouze v lineární podobě atd. $\mathrm{V}$ další kapitole se proto budeme věnovat již pouze pedagogickému výzkumu, a to v kontextu Československa.

\section{2 „První rande u nás“: pedagogický výzkum od dob Československa}

Pedagogický výzkum má u nás historickou tradici. Česká pedagogika jakožto věda se začala vytvářet koncem 19 . století. Za historický prvopočátek vědecké pedagogiky u nás lze považovat rok 1882, kdy byl na pražské univerzitě 
ustanoven první profesor pedagogiky G. A. Lindner (Průcha, 2009). Patrně nejstarší výzkumy, které se odehrály pod vlivem reformního pedagogického hnutí, se týkaly výukových metod a realizovaly se již za první republiky. Představiteli těchto výzkumů byli V. Př́hoda, O. Chlup, S. Vrána a mnozí další (Janíková \& Vlčková, 2009). Výzkumné instituce však stály i mimo univerzity, jako např́íklad liberecký Ústav pro vědy duševní a výchovné založený v roce 1923 (Kasper, 2007).

Vztah výzkumu a výuky lze pak sledovat ve 2 . polovině 20 . století. Ve zpětném pohledu na komunistické Československo dle Šimy a Pabiana (2013) převládá názor, že výzkum a výuka byly odděleny - zejména přesunem výzkumu na Akademii věd, což vedlo k omezení vědeckého výzkumu v profesi vysokoškolských pedagogů. Autoři však postulují, že minimálně v ideologické rovině tomu bylo obráceně a že „komunistická vysokoškolská pedagogika byla po celých čtyřicet let založena na ideologii neoddělitelného spojení výuky a výzkumu na vysokých školách“ (Šima \& Pabian, 2013, s. 61). Autoři dále upozorňují na absenci české odborné debaty o tomto principu. V české pedagogické vědě je však silně přítomno téma vědy a pedagogické praxe, které se v tomto období objevuje přibližně od konce 70. let 20. století. Skalková (1979) hovoří o komplexním svazku vědy s praxí: „Má-li pedagogika plnit své náročné úkoly, je nezbytné neustále prohlubovat a zkvalitňovat procesy jejího vědeckého poznávání a uplatňování poznatků v praxi“ (s. 467). Podobně uvažuje Průcha (1985) o sbližování pedagogického výzkumu s potřebami praxe a definuje také uživatele výsledků výzkumu, mezi kterými zmiňuje mimo jiné pracovníky produkující a konzumující vědecké informace (vědecké a odborné pracovníky v pedagogice a dalších disciplínách). Dotýká se tedy i významu výzkumu pro vysokoškolské učitele. V 90. letech je pak téma vztahu vědy, výzkumu a praxe výrazněji akcentováno i na konferencích, zejména na konferenci České asociace pedagogického výzkumu konané v roce 1993. Kotásek (1993) ve svém referátu na této konferenci uvádí, že se „ve vzdělávání učitelů na univerzitách doporučuje, aby jejich odborná př́íprava byla co nejvíce spojena s výzkumnou prací. Zvláštní pozornost vedení univerzity si zaslouží pedagogické fakulty, které spojí interdisciplinární výzkum školství a vzdělání s výukou budoucích učitelů“ (s. 367). Podle Kotáska (1993) se tím univerzity zasadí o důvěryhodnost učitelů jako členů obce intelektuálů. V další dekádě již nalezneme pojetí učitele jako výzkumníka a vyzdvihnutí významu výzkumných dovedností pro učitele: „Učitelé se učí získávat odstup od vlastní praxe, od subjektivních zkušeností, učí se v roli ,výzkumníka' 
analyzovat vlastní praxi - rozhodovací procesy, konkrétní výukové situace a na základě toho modifikovat své strategie výuky, navrhovat alternativní řešení a opatření ke zkvalitnění výuky“ (Spilková, 2006, s. 22).

Na základě zkušeností z lékařství se ve Velké Británii devadesátých let diskutují možnosti založení edukační praxe na důkazech, které získává pedagogický výzkum (Mareš, 2009). Vznikla nová oblast nesoucí název edukace založená na důkazech (evidence-based education) a je jí věnována pozornost i v české pedagogické vědě. Edukace založená na důkazech částečně může propojovat výzkum a výuku, přestože koncept je širší (srov. Mareš, 2009). Zároveň nese edukace založená na důkazech rizika v redukci pojetí pedagogického výzkumu pouze pro účely praxe (srov. Pol \& Švaříček, 2011; Švaříček, 2013; Štech, 2009). Přestože se tedy úvahy o spojení výzkumu a výuky v pregraduální př́ípravě učitelů $\mathrm{v}$ různých konceptech objevují, diskuse o nich u nás na rozdíl od zahraničí není prŕiliš bouřlivá.

Vrátíme se proto zejména do angloamerického kontextu, kde se k tématu hojně publikuje. Zaměříme se na vztah výzkumu a výuky na univerzitách, nejen na pedagogických fakultách, nebot' se jedná o určující kontext pro další úvahy. Jsme si vědomi značných kulturních a politických odlišností, přesto jsou tyto debaty pro nás zajímavé, nebot' postupně prosakují i do českého vzdělávacího diskursu. Prvním z problematických bodů je pojmenování řešené problematiky vztahu výzkumu a výuky.

\section{3 „Hledání společného jména“: výzkum a výuka v terminologickém pohledu}

Spojení výzkumu a výuky můžeme chápat jako specifický koncept, pro který je vhodné najít přiléhavé označení. V mezinárodní debatě se užívají pojmy, které zahrnují různou podobu propojení výzkumu a výuky: spojení výzkumu a výuky (teaching-research nexus), výuka založená na výzkumu (research-based teaching), výuka vedená výzkumem (research-led teaching), badatelsky orientovaná výuka (inquiry-based teaching), výzkumně podložená výuka (research-informed teaching), výzkumně orientovaná výuka (research-oriented teaching) a další (Geschwind \& Broström, 2013; Griffiths, 2004; Healey \& Jenkins, 2005, 2006; Willcoxson, Johnston, \& Gething, 2011). Neměli bychom zapomenout ani na zmíněný koncept vyučování založeného na důkazech (evidence-based teaching či evidence-based education), který také 
odkazuje k vlastnímu výzkumu výuky, studentů, absolventů, zaměstnanců, univerzity (Biggs \& Tang, 2011).

To je ale jen jedna strana mince. Pracuje se také s koncepty, v nichž je slovo „teaching" nahrazeno slovem „learning“. V literatuře se píše zejména o badatelsky orientovaném učení (inquiry-based learning; Reinventing undergraduate education, 1998) nebo o učení se ve výzkumném módu (learning in a research mode; Barnett, 2005). Tyto koncepty zdůrazňují, že učení se děje skrze aktivitu studentů, tedy že podstatou není to, co dělá učitel, ale to, co dělají studenti (Biggs \& Tang, 2011). K akcentování vyučování i učení se zároveň směřuje koncept vyučování a učení založeného na výzkumu (research-based teaching and learning), pro který autoři užívají akronym RBTL (Pawelleck \& Brendl, 2013). Ten zahrnuje jak orientaci na výzkum učitele, tak i na učení se studenta $v$ kontextu výzkumu. Celkově také proměňuje pohled na vysokoškolské vzdělávání tím, že učitele a studenty k sobě přibližuje. Učitelé by v tomto pojetí měli vidět nejen studenty, ale i sami sebe jako učící se jedince (Kossek, cit. podle Pawelleck \& Brendl, 2013). Vyučování a učení založené na výzkumu akcentuje jak výzkumné dovednosti vysokoškolských učitelů, tak také zdůrazňuje integraci výzkumu do výuky (Pawelleck \& Brendl, 2013). Shledává benefit v propojení výzkumu a výuky odkazem na tezi Johna Deweyeho: Učení je založeno na objevování vedeném mentorem spíše než na transmisi informací (Reinventing undergraduate education, 1998).

Jednotlivé přístupy spojující výzkum a výuku se pokusili utřídit Healey a Jenkins (2005). Ve svém schématu rozlišují tyto přístupy dle dvou kritérií: (1) zda je přístup zaměřen na studenty nebo na učitele a (2) zda se v něm klade důraz na vybraný obsah výzkumu nebo na výzkumný proces jako takový. Na základě těchto kritérií můžeme rozlišit čtyři přístupy (obrázek 1). 


\section{ZAMĚŘENO NA STUDENTY \\ (studenti jako participanti)}

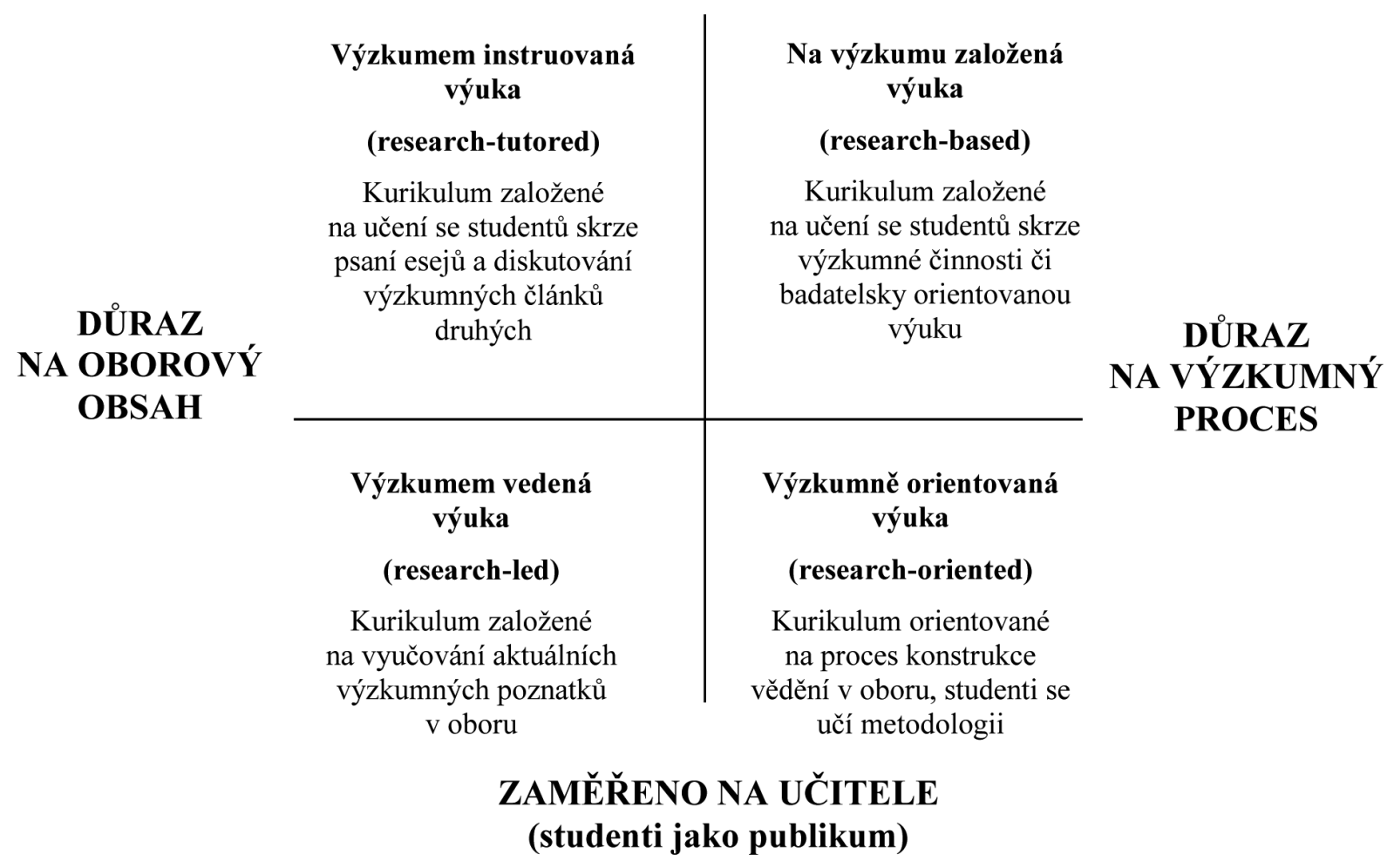

Obrázek 1. Typologie spojení výzkumu a výuky. Převzato z Healey a Jenkins (2005, s. 22).

Přístup výuky instruované výzkumem (research-tutored teaching) je zaměřen na studenta a na obsah oboru. Ilustrován je jako psaní a diskutování esejů, při kterém se studenti aktivně zapojují do evaluování a kritického hodnocení výzkumu druhých.

Orientace na studenta je také znakem výuky založené na výzkumu (research-based teaching). V tomto přístupu se studenti stávají výzkumníky například v rámci badatelsky orientované výuky či tvorby závěrečné práce. Kurikulum je namísto tradičního obsahu disciplín (Griffiths, 2004) organizováno kolem výzkumných záměrů (Healey \& Jenkins, 2005) a důležitý je samotný proces konstrukce vědění. Studenti se učí v roli výzkumníků a rozdíly mezi učiteli a studenty se stírají (Healey \& Jenkins, 2005). 
V př́stupu výuky vedené výzkumem (research-led teaching) se orientujeme spíše na vysokoškolské učitele (Healey \& Jenkins, 2005). V tvorbě kurikula dominuje výzkumný zájem učitele (Jongh et al., 2014) a studenti vystupují jako publikum, které je př́ijemcem těchto výzkumných sdělení. $V$ podstatě se studenti učí o výsledcích výzkumu (learning about outcomes), jak popisuje Barnett (2005).

V posledním př́stupu výzkumně orientované výuky (research-oriented teaching) se studenti učí o výzkumném procesu a o tom, jak jej realizovat. V kurikulu je kladen stejný důraz na proces, ve kterém student získá vědomost, jako na vědomost samotnou. Dle Barnetta (2005) toto pojetí můžeme označit jako učení se výzkumné metodologii (learning to do research). Fakulta navozuje výzkumný étos (Healey \& Jenkins, 2005) v pregraduálním vzdělávání učitelů.

Všechny čtyři přístupy lze shledat jako užitečné. Nemusí se přitom vzájemně vylučovat, některý z přístupů může v kurikulu pouze dominovat. Jaký termín ale zvolit pro koncepci pregraduální př́ípravy učitelů, která akcentuje synergii výzkumu a výuky? Z terminologického bludiště vykročíme využitím konceptu edukace založené na výzkumu (research-based education; Geschwind \& Broström, 2013), který však již nasměrujeme do učitelského vzdělávání. Spojení výzkumu a výuky v oblasti učitelského vzdělávání zachycuje edukace učitelů založená na výzkumu (research-based teacher education), která je důkladně rozpracovaná zejména ve Finsku (Kansanen, 2006, 2011, 2014). Vzdělávání učitelů ve Finsku naplňující tuto koncepci je zmiňováno jako jeden $\mathrm{z}$ předpokladů úspěchu finských žáků v mezinárodních výzkumech srovnávajících výsledky vzdělávání (Kansanen, 2014). V tomto přístupu studenti učitelství jako součást výuky praktikují výzkum. Výzkum však neslouží primárně k publikování vědeckých textů, nýbrž pro potřeby praxe. Budoucí učitelé jsou pak schopni využívat poznatků z výzkumu při posuzování svých rozhodnutí v praxi a reflektovat svoji práci výzkumnou optikou. Spojení výzkumu a výuky v pregraduálním vzdělávání učitelů můžeme nazvat dvojitou praxí (Kansanen, 2014). Výstupem vzdělávání učitelů, ke kterému tento přístup vede, je podle Kansanena pedagogické myšlení. ${ }^{1}$ Samozřejmě tento př́stup klade požadavky i na vysokoškolské učitele. Ti by měli mít výzkumné znalosti a dovednosti na vysoké úrovni (Kansanen, 1991, 2011).

1 Jedná se o metakognitivní kompetenci studentů či učitelů, která spočívá ve vyhodnocování rozhodnutí na základě edukačních cílů (Kansanen, 1991, 2011). 
Přestože je v edukaci učitelů založené na výzkumu shledáván velký potenciál k přípravě autonomních učitelů (Munthe \& Rogne, 2015), jsou v ní pojmenována i některá rizika. Ve vysokoškolské př́ípravě učitelů zůstává výzkum $\mathrm{s}$ výukou mnohdy nepropojen, výzkumníci a studenti spolu nejsou v interakci, na univerzitách se prohlubuje mezera mezi výzkumníky a učiteli, jako by vědění nebylo spjato s obojím - výukou i výzkumem (Barnett, 2005). Učitelé v praxi pak mnohdy ve výzkumu nevidí přínos. Řada učitelů nevyužívá výzkumné poznatky, a přesto můžeme jejich výuku označit za efektivní (Hammerseley, 1997). V neposlední řadě výzkumu nemusí přát ani univerzitní prostředí, ve kterém situaci skholé ${ }^{2}$ nahradila zcela jiná situace, pro kterou je typické, že vzrostly jak kvantitativní, tak i kvalitativní požadavky na výzkumníky. Mají učit více studentů, než tomu bylo kdy dříve, a zároveň mají být jejich vědecké výsledky porovnatelné s mezinárodní, nejen národní konkurencí (Wiegerová et al., 2013). Na funkční propojení výzkumu a výuky $\mathrm{v}$ pregraduálním vzdělávání učitelů se zaměříme na příkladu kvalitativního výzkumu.

\section{4 „Společná cesta životem“: příklad kvalitativního výzkumu}

Volba kvalitativního výzkumu pro ilustraci vztahu výzkumu a výuky není vymezením se vůči výzkumu kvantitativnímu či povyšováním jednoho z př́istupů nad přístup druhý. Právě kvalitativní výzkum bývá někdy označován jako „ten druhý“ a jeho pozice na poli společenskovědních disciplín je mnohdy méně pevná. Kvalitativní výzkumy pracují s nereprezentativními vzorky a obtížnou či nemožnou zobecnitelností. Zřídka formulují aplikační cíle, namířené například do vzdělávací politiky, jako je tomu často u mezinárodních srovnávacích výzkumů (srov. Froese-Germain, 2011). Zamýšlení se nad kvalitativním výzkumem $\mathrm{v}$ pregraduálním vzdělávání učitelů tak může být větší výzvou. Hlavním důvodem volby kvalitativní metodologie je však její podstata směřující k hloubkovému porozumění, která rezonuje s naším pojetím vysokoškolské výuky i pedagogické praxe.

Šírii debaty omezíme také tím, že se zaměříme pouze na hledání možných vazeb a transferů poznatků ve výzkumu a ve výuce. Uzavřené necháme např́iklad strukturální otázky financování vysokého školství, akreditace či

2 Vysokoškolské prostředí přelomu 80. a 90. let popsané Pierrem Bourdieu jako prostředí odříznuté od spěchu každodenního života a utilitarismu trhu práce (Wiegerová et al., 2013). 
neoliberalismu (ten je dle mnohých autorů v rozporu s humboldtovským principem jednoty výzkumu a výuky), které mohou stavět výzkum a výuku do neslučitelných pozic. Naším cílem tedy není problematiku výzkumu a výuky komplexně řešit, nýbrž k ní otevřít debatu skrze konkretizaci jednoho z jejich potenciálních pojítek, kterým může být kvalitativní výzkum.

Kvalitativní výzkum se rozvíjí od 70. let 20. století. Kvalitativní výzkum vymezuje Creswell (2012, s. 15) jako výzkumný proces založený na porozumění sociálním či lidským problémům, v němž výzkumník reportuje detailní pohled informantů a výzkum realizuje v přirozeném prostředí. Kvalitativní výzkum pomáhá výzkumníkům porozumět chování lidí v určitém sociálním a kulturním kontextu (Hazzan \& Nutov, 2014). To je také záměrem pedagogických věd a ani pedagogické vědy proto nezůstávají pozadu v realizaci kvalitativních výzkumných studií. $\mathrm{V}$ české pedagogice se zejména v posledních dvou dekádách kvalitativní metody sběru a analýzy dat stávají rozšířeným a akceptovaným způsobem bádání. Pokusíme se nahlédnout na potenciální význam kvalitativního výzkumu pro studenty učitelství, vysokoškolské učitele a v neposlední řadě i pro pedagogickou vědu.

\subsection{Význam kvalitativního výzkumu pro studenty učitelství}

Tím, co spojuje autory hledající jednotu výzkumu a výuky na vysokých školách, je důraz na zkušenostní učení studentů. Studenti jsou povzbuzováni, aby znovuobjevovali vědění. Toto pojetí odpovídá dle Barnetta (2005) humboldtovskému badatelskému učení (forschendes Lernen) či učení se ve výzkumném módu (learning in a research mode). Vědění ve výuce i ve výzkumu totiž není nikdy plně vyřešeno, proto je neustále ve výzkumném módu a univerzity by měly takto k vědění přistupovat. Barnett (2005) však kriticky poznamenává, že tato idea vedla zejména $\mathrm{v}$ německy mluvících zemích k rozkvětu výzkumu na univerzitách v posledních 150 letech, ale výuku proměnila jen málo. Zůstává se u lekcí, v nichž dominuje učitel. Teprve v posledních třiceti letech zejména v anglosaském prostředí dochází dle Barnetta (2005) $\mathrm{k}$ posunu od výuky orientované na učitele (teacher-centred teaching) k učení orientovanému na studenta (student-centred learning). $\mathrm{V}$ dnešní době $\mathrm{k}$ tomu vede např́íklad problémové učení (Barnett, 2005). Také u nás je výuka orientovaná na studenta velkým tématem. Švec (2006) zdůrazňuje potřebu více orientovat pedagogickou přípravu zkušenostně. Jde o postup, v němž student k teorii dochází na základě reflektovaných zkušeností (prostřednictvím empirické a abstrahující reflexe), společných diskusí s kolegy a vzdělavateli 
učitelů. Spilková (2006) v kontextu učitelské přípravy přímo hovoří o učiteli jako o výzkumníkovi, ke kterému v pregraduální př́ípravě dojdeme prostřednictvím investigativních přístupů, rozvoje kritického myšlení, reflexe a sebereflexe. Realitu vysokoškolské výuky v Česku zmapovali v etnografickém výzkumu Dvořáčková a kol. (2014), kteří v kontrastu s výše postulovaným zjistili, že „převažuje frontální prezentace vědění spolu s minimální aktivní participací studujících na utváření toho, co se učí (s. 40), a to překvapivě jak na přednáškách, tak i na seminářích. K oslabení jednostranné poznatkové transmise může přispět právě studentské bádání, které může vyvolat větší chut' studentů poznávat věci nezprostředkovaně.

Právě kvalitativní výzkum může studentům nabídnout atraktivní př́iležitost ke spoluutváření vědění, byt' je na první pohled v rozporu s očekáváním studentů. Studenti dle našich zkušeností často očekávají od pedagogických fakult, že jim dají jasné a neměnné návody, jak řešit pedagogické situace. Očekávají, že obdrží vědění, které lze použít bez ohledu na specifika aktérů a situací, a hlavně bez hlubšího vhledu do situace. Někdy jsou taková doporučení a metodiky potřebné a funkční, avšak podstata učitelského vzdělávání netkví v takovémto „instantním vědění“. To samo o sobě nevede k autonomnímu výkonu profese. Instantní vědění může být i riskantní, nedoprovází-li jej porozumění pedagogické realitě, dovednost ji autonomně dekódovat a analyzovat. Jednou z cest, jak rozvíjet tuto klíčovou dovednost, je kvalitativní výzkum jako součást edukace učitelů založené na výzkumu (research-based teacher education).

Setkání studentů s výzkumem má na pedagogických fakultách často podobu metodologických kurzů. Začlenění metodologických kurzů v pregraduální př́ípravě učitelů však budí rozpaky. Nepřipravujeme přece vědce, nýbrž učitele (srov. Kansanen, 2011). V éře masifikace vysokoškolského vzdělávání ${ }^{3}$ se vědci stane jen minimální část absolventů pedagogických fakult. Tak proč studenty trápit s něčím tak „neužitečným“, jako je metodologie pedagogických věd? $\mathrm{V}$ tomto textu pohled na metodologii, konkrétně kvalitativní, obracíme. Budeme nahlížet na kvalitativní výzkum jako na něco užitečného v každodenní práci učitele. Čím jiným je totiž učitelská profese než prací s daty převážně kvalitativního charakteru? Učitel neustále pozoruje dění ve třídě, hovoří se žáky, hodnotí a interpretuje výsledky jejich činnosti

3 Tzn. nárůst počtu studentů vysokých škol. Podrobněji tento trend analyzují Prudký, Pabian a Šima (2010). 
a v ideálním př́ípadě i sám sebe. Proto je také pro studenty učitelství užitečné nahlédnout na vzdělávací realitu jako na soubor rozmanitých kvalitativních dat. Cílem tedy není vychovat ze studentů špičkové kvalitativní výzkumníky, ale zcitlivovat je $\mathrm{v}$ práci s kvalitativními daty každodennosti a vést je $\mathrm{k}$ jejich interpretování. S tím souvisí i pohled na pedagogickou vědu jako na něco živého, co je utvářeno výzkumem. Studenti tak mohou lépe porozumět tomu, jak je vědění konstruováno, což může být v době publikačního boomu a snadného přístupu k mezinárodním publikacím významnější než vědění samotné, které může zastarat ještě dříve, než student odpromuje.

$\mathrm{Na}$ př́íkladu kvalitativního výzkumu $\mathrm{v}$ přípravě budoucích učitelů představíme šest př́stupů, které mohou naplňovat edukaci učitelů založenou na výzkumu:

\section{a) Studenti se učí o kvalitativním výzkumu}

Studenti se učí „o kvalitativní výzkumné metodologii“, nikoliv „dělat kvalitativní výzkum“ (srov. Štech, 2014). Typickým příkladem mohou být metodologické kurzy kvalitativního výzkumu formou přednášky. Takové vzdělávání je užitečné zejména jako kombinace s dalšími př́ístupy.

\section{b) Studenti se učí dělat kvalitativní výzkum}

Na rozdíl od předchozího přístupu se zde studenti učí „dělat kvalitativní výzkum" tím, že realizují vlastní kvalitativní výzkumné šetření. Porozumí tudíž lépe tomu, jak je vědění konstruováno (Norton, 2009). Rozvíjí ale rovněž dovednosti pro praxi: argumentaci, rozhodování a ospravedlňování řešení pedagogických problémů (Kansanen, 2014). Tento př́stup se může odehrávat v metodologických seminářích nebo při tvorbě závěrečných prací. Vybrané studentské výzkumy realizované $\mathrm{v}$ rámci závěrečných prací mohou být publikovány i ve vědeckých časopisech (např. Studia paedagogica). Jak zjistila Wiegerová a kol. (2013), studenti preferují volbu kvalitativního výzkumu pro tvorbu závěrečné práce, přestože o něm nemají přesné povědomí. Příprava studentů na výzkumnou práci z hlediska formálního vzdělávání na univerzitách je dle autorů nedostatečná a je proto výzvou pro pedagogické fakulty. Studenti se v tomto př́stupu spolupodílejí na utváření kurikula volbou vlastního výzkumného problému. 


\section{c) Studenti jsou partnery akademiků ve výzkumných projektech}

V tomto př́stupu se studenti také učí realizací kvalitativního výzkumu, avšak „naostro". Nejsou tedy výzkumníky v hájeném prostředí semináře či tvorby závěrečné práce, nýbrž ve výzkumném projektu podpořeném některým z výzkumných schémat. Rozdíly mezi učiteli a studenty se stírají, nebot' obě strany vystupují ve stejné roli.

Jako př́klad uvedeme projekt specifického výzkumu (MUNI/A/1317/2014). Projekt byl zaměřen na výzkum interakce studentů učitelství se žáky v průběhu praxe (Lojdová, 2015). V rámci projektu jsme sestavily výzkumný tým, který se od ledna 2015 do prosince 2015 zabýval zkoumáním interakce studentů učitelství se žáky v průběhu učitelské praxe na základních školách. Členy týmu byly čtyři studentky navazujícího magisterského studia učitelství na Pedagogické fakultě MU a jedna akademická pracovnice. Vzhledem k výzkumnému problému byl zvolen kvalitativní výzkumný design. Data byla sbírána metodou ohniskové skupiny se studenty učitelství na praxi a psanou výpovědí od žáků, u kterých tito studenti praktikovali. Výsledky výzkumu studentky publikovaly nejen v diplomové práci, ale i v monografii a na konferenci, tedy v médiích určených profesionálním výzkumníkům. Studentky získaly v rámci projektu nadstandardní zkušenosti z oblasti metodologie, týmové práce a prezentace odborného textu. Získaly zpětnou vazbu ke své práci nejen od školitelky, ale také od recenzentů kapitoly v monografii a od publika na konferenci. Jedna ze studentek projevila na základě účasti v projektu zájem o doktorské studium. Podstatné však také je, že se studentky hloubkově zabývaly tématem, které je pro ně profesně relevantní - interakce studenta učitelství se žáky - a se kterým měly v době výzkumu žitou zkušenost. Řešení výzkumného problému odpovídalo jejich potřebám v daném vývojovém období profesní dráhy. Kurikulum učitelského vzdělávání se tímto zplnomocněním studentů $\mathrm{k}$ výzkumu proměňuje. Znalosti nabyté ve výzkumném projektu odpovídají profesní každodennosti, jsou interdisciplinární a lze je konfrontovat s praktickou zkušeností.

\section{d) Studenti spolu s vysokoškolskými učiteli konstruují vědění induktivně na zá- kladě analýzy kvalitativních dat}

V tomto pojetí může jít o diskusi kvalitativních výzkumů či samotných kvalitativních dat v seminářích. Studenti mohou za pomoci učitele s daty induktivně pracovat. $\mathrm{K}$ teoriím tak dochází $\mathrm{s}$ učitelem společně na základě dat. Nemusí se přitom jednat jen o výzkumy druhých, studenti a učitelé mohou 
pracovat i s daty, která seberou přímo v semináři. Příkladem je narativní analýza zkušeností studentů učitelství se skrytým kurikulem ve škole. Studenti psali v semináři vlastní příběh, který zachycoval jejich negativní zkušenost se školou. Následně v semináři proběhla analýza anonymizovaných textů s cílem zjistit, s jakými podobami skrytého kurikula se studenti setkali. Téma skrytého kurikula tak nabylo konkrétních podob a jeho teorie byla společně konstruovaná na základě interpretace dat. Takto sebraná data byla využita k publikaci vyučující semináře (Lojdová, 2015).

V práci se svými daty nebo s daty druhých se jedná o konstrukci induktivního vědění. Kvalitativní výzkum je totiž především způsobem uvažování o sociální a edukační realitě, hledáním porozumění, které je postaveno induktivně a konstruktivisticky. To zároveň může být cílem seminářů ve vysokoškolské výuce. Podle zkušenosti z vlastní výuky zjištujeme, že takovou výuku hodnotí studenti jako praktickou. Přitom se jedná o propojení teorie s praxí, a to právě skrze kvalitativní výzkum. Učitel je zde facilitátorem, který vede proces poznávání studentů a utváŕí kurikulum, jak popisuje Barnett (2005), ve výzkumném módu. Není předem známo, jaká teorie vznikne, nebot' interpretace studentů mohou vnést do teorie pohledy, které nemusí obsahovat původní studie.

e) Vysokoškolští učitelé učí kurzy, jejichž obsahem jsou poznatky z vlastního (kvalitativního) výzkumu a z významných výzkumů v oboru

Tento př́ístup přibližuje například Norton (2009). V tvorbě kurikula dominuje výzkumný zájem učitele (Jongh et al., 2014) či aktuální výzkumná témata pedagogické vědy. Vysokoškolští učitelé staví výuku na nejnovějších poznatcích založených na výzkumu a vedou studenty k četbě výzkumných zpráv.

\section{f) Vysokoškolští učitelé dělají (kvalitativní) výzkum své praxe}

Vysokoškolští učitelé dělají (kvalitativní) výzkum své výukové praxe, což ji může zlepšit (Norton, 2009). V tomto případě se vysokoškolští učitelé zabývají výzkumem výuky, studentů učitelství i sebe samých (Cochran-Smith, 2005). Ve výzkumu výuky vysokoškolských učitelů lze shledat potenciál ke zlepšení práce se studenty, porozumění studentům učitelství i sobě samým. Př́kladem může být výzkum studentů učitelství na praxi (Vlčková et al., 2015) vysokoškolskými učiteli, kteří zároveň vedou semináře k učitelské praxi na fakultě. Výzkum přinesl vysokoškolským učitelům vhled do zkušenosti studentů na praxi a generoval poznatky využitelné v semináři. To je prŕístup, který má na studenty vliv zprostředkovaně. 
Tyto typy edukace učitelů založené na výzkumu se mohou vzájemně kombinovat a doplňovat tak, aby z nich profitoval student učitelství, a to zejména tím, že rozvíjí své myšlení dle kritérií výzkumu, avšak nikoliv jen pro vědu, nýbrž pro každodenní rozhodování v pedagogické praxi. Studenti se skrze výzkum učí otevřenému přístupu k problémům a rozvíjí metakognitvní dovednosti (Kansanen, 2006). Modelově jsme představili možné podoby spojení výzkumu a výuky. Empirický výzkum, který mapuje realitu výzkumu na pedagogických fakultách, se uskutečnil na Fakultě humanitních studií UTB ve Zlíně. Wiegerová a kol. (2013) v tomto výzkumu zjistili, že magisterští studenti pedagogických oborů většinou nemají přímé zkušenosti s výzkumem, nemají zájem o výzkum nebo nemají povědomí o tom, že se s výzkumem potkali. Avšak u studentů, kteří mají jasnou představu o výzkumu, se objevovaly náznaky benefitů vyplývající z výzkumné činnosti. Autoři také identifikovali některé překážky začlenění výzkumu do výuky. Je to zejména silná motivace studentů k uplatnění se na trhu práce, která vytváří pasivitu $\mathrm{k}$ vědě a výzkumu. Studenti také disponují naivními představami o výzkumu, které je však možné zkoumat. Wiegerová a kol. (2013) téma uzavírají tím, že zlepšení vztahu studentů k výzkumu je v rukou vysokoškolských pedagogů, ale i studentů samotných.

Pokud bychom chtěli benefit z výzkumu pro studenty pojmenovat jedním slovem, můžeme použít termín zplnomocnění studentů (student empowerment). Zplnomocnění studentů zahrnuje (a) podíl na ovlivňování obsahu kurzu ve spolupráci s vysokoškolským učitelem, (b) hlas studentů učitelství ve vzdělávání, (c) prostor pro vlastní volbu studentů a jejich kreativitu (Bryer \& Seigler, 2012). To dle autorů vede k větší odpovědnosti studentů za učení (ownership) a může dokonce vzbudit vášeň pro učení. Tyto body kvalitativní výzkum v edukaci učitelů založené na výzkumu zahrnuje a může je různými způsoby naplňovat. Steinberg a Kincheloe (2002) zdůrazňují, že studenti (týká se všech - od žáků základních škol přes středoškoláky po vysokoškolské studenty) jako výzkumníci umí nejen porozumět světu, ale umí ho i změnit. Zplnomocnění studentů vidí ve vztahu k pedagogické i sociální realitě. Kvalitativní výzkum tak může být jedním z kriticko-pedagogických nástrojů směřujících $\mathrm{k}$ přípravě učitele - kritického intelektuála a aktéra sociální změny (McLaren \& Kincheloe, 2007). To, že věda ovlivňuje společnost více, než se oficiálně přiznává (a to pozitivně i negativně), popisuje Stöckelová (2012). Kvalitativní výzkum tak může být mocnějším nástrojem v rukou učitelů, než se na první pohled zdá. 
Zdůrazňujeme tedy,ževýznam kvalitativního výzkumu přesahuje profesní přípravu na vysoké škole i RIVové body. Pedagogický výzkum nemá činit učitele pouhým objektem svého zkoumání, ale měl by se dít z pozic učitelů. Proto se také prosazuje princip zařazování aktivního výzkumu do dalšího vzdělávání učitelů a do činnosti jednotlivých škol (Kotásek, 1993). Kvalitativní výzkum tudíž rozvíjí kompetence studentů učitelství pro učitelskou praxi - a to k porozumění edukační realitě i k jejímu systematickému vyhodnocování -, které mohou učitelé dále systematicky realizovat například akčním výzkumem. Právě akční výzkum je diskutován jako prostředek rozvoje autonomie učitelů v každodenní praxi (srov. Gratch, 2002; Kansanen, 2011; Klehr, 2012; Lee, 2014). Jiným příkladem metodologie zajímavé pro učitele jsou videostudie výuky, které dokumentují pedagogické jevy v surovější podobě než například rozhovory či pozorování, při kterých může dojít k subjektivnímu zkreslení. Data z (vlastní) videostudie výuky lze navíc analyzovat jak kvalitativně, tak i kvantitativně (Janík \& Najvar, 2008) a mohou být podkladem pro sebereflexi učitele.

Učitel, který projde výzkumně orientovaným vzděláváním, není profesionálním výzkumníkem, ale výzkumníkem-praktikem. To znamená, že nerealizuje výzkum (resp. myšlení dle kritérií výzkumu) za účelem publikování výsledků ve vědeckých časopisech, nýbrž za účelem svého profesního růstu a zlepšení své praxe. V tomto smyslu učitel výzkum produkuje, ale důležité je, že dokáže výzkum také konzumovat, tj. číst výzkumné zprávy a rozumět jim (Kansanen, 2014), včetně výsledků vlastního výzkumu. V pregraduálním vzdělávání budoucích učitelů směřujeme $\mathrm{k}$ výzkumníkům-praktikům, přičemž menší část z nich se může vydělit, stát se výzkumníky-profesionály, a pokračovat $\mathrm{v}$ doktorských studijních programech. Výzkum prováděný učitelem je dle Průchy, Walterové a Mareše (2013) trendem směřujícím k tomu, aby se učitelé podíleli na výzkumech jako spolupracovníci nebo sami prováděli dílčí výzkumy ve svých školách. Toto změní edukační realitu ve smyslu efektivnějšího zavádění inovací do výuky či lepšího poznávání žáků ze strany učitelů.

Na kvalitativní výzkum jako součást edukace učitelů založené na výzkumu nahlížíme jako na prostředek, který má potenciál posilovat profesní autonomii absolventů pedagogických fakult a napomáhat jim na cestě k expertnosti. Koncept edukace učitelů založené na výzkumu kromě studentů zahrnuje i vysokoškolské učitele. Přirozeně se nám tedy objevuje otázka, jaký význam má kvalitativní výzkum pro ty, kteří připravují budoucí učitele. 


\subsection{Význam kvalitativního výzkumu pro vysokoškolského učitele}

Mnohé výzkumy hovoří jasně pro výzkum v profesi vysokoškolského učitele. Například dle výzkumu Švédské národní agentury pro vysokoškolské vzdělávání (Swedish national agency for higher education) z roku 2003 si $90 \%$ univerzitních učitelů ve Švédsku myslí, že je pro ně důležité až velmi důležité mít možnost realizovat vlastní výzkum a $99 \%$ si myslí, že je důležité až velmi důležité, aby vysokoškolská výuka byla založená na výzkumu (Geschwind \& Broström, 2013). Připisování významu výzkumu má však svá oborová specifika. Ve vztahu k učitelům Chetty a Luben (2010) zjistili poněkud odlišný pohled. Většina vzdělavatelů učitelů v jejich výzkumu považuje výzkum a výuku za dichotomní elementy a výzkumné aktivity jsou pro ně způsobem uspokojení institucionálních požadavků a obdržení finanční podpory. Dalším důležitým prvkem do této mozaiky je to, jaké kariérní cesty vedou k profesi vysokoškolského vzdělavatele učitelů. Například v Portugalsku se jimi většinou nestávají zkušení učitelé z praxe, zatímco ve Velké Británii ano. Akademická identita je přitom ovlivněna touto individuální autobiografií (Lopes et al., 2014; Robinson \& McWilliam, 2006).

Vzdělavatelé učitelů se na základě různých kariérních drah mohou ocitnout na pomezí tři profesí: učitel v primárním či sekundárním vzdělávání, vzdělavatel učitelů na vysoké škole a výzkumník. To, co mezi tyto profese staví bariéry, mnohdy není jejich podstata, nýbrž institucionální podmínky. Jak ukazují Lopes a kol. (2014), vysokoškolští učitelé neodmítají produkci vědění a publikování výsledků vědecké práce, ale spíše vypovídají o obtížnostech v jejich souběžném zvládání. Problematické je pro ně také propojení jejich výzkumu a výuky. Důraz na výzkum definovaný publikačními výstupy s co nejvyšším bodovým hodnocením tak může být pro koncept edukace učitelů založené na výzkumu spíše kontraproduktivní. Vysokoškolský učitel směřuje výsledky svého výzkumného úsilí spíše k hodnotitelům výzkumu než ke studentům.

V opačném pohledu se může kvalitativní výzkum stát pro vysokoškolské učitele jednou ze spojnic teorie s praxí. Kvalitativní výzkum je naturalistický. Výzkumník obvykle setrvává delší dobu v terénu, zejména u etnografických studií i v řádu let. ${ }^{4}$ Vysokoškolští učitelé vzdělávající budoucí učitele jsou tak díky kvalitativnímu výzkumu $\mathrm{v}$ kontaktu se současnou školskou praxí. Nemusí se přitom jednat o náročný etnografický výzkum. Například

4 Ukázkou takového přístupu je v našem prostředí např. longitudinální výzkum Pražské skupiny školní etnografie (viz http://kps.pedf.cuni.cz/psse). 
pro kvalitativní výzkum typické hloubkové rozhovory s aktéry vzdělávání přináší vysokoškolskému učiteli jedinečný kontakt se současnou vzdělávací realitou. Tento kontakt je přitom odlišný od toho, který někteří z nich mají ze svého minulého či souběžného působení v primárním nebo v sekundárním vzdělávání. Výzkumná pozice jim zároveň umožňuje přistoupit k edukační realitě s větším odstupem a více analyticky. Tento „analytický vhled“ mohou vysokoškolští učitelé využít nejen ve výzkumu, ale i ve výuce.

Realizace kvalitativního výzkumu také definuje profesi vysokoškolského učitele. Kansanen (2006) řŕká, že zatímco učitel ve škole „učí z učebnic“, vysokoškolský učitel učí na základě svého výzkumu. Kvalita vysokoškolského vzdělávání závisí do určité míry na kvalitě vysokoškolského učitele jako výzkumníka. Tomu kontruje Barnettova hudební metafora: „Výzkum k výuce se má jako notový zápis k provedení skladby. Pro interpretaci není nutné, aby byl hudebník skladatelem. Stačí, aby znal partituru, aby ji dokázal originálně interpretovat." (Šima \& Pabian, 2013, s. 20) Dle Barnetta tedy není nutné, aby vysokoškolský učitel realizoval vlastní výzkum, dostačuje jeho didaktická dovednost. Skrze vlastní výzkum však vysokoškolský učitel nepřehrává jen part zapsaný v notovém zápisu, ale vytváří part vlastní. Z interpreta se stává skladatelem. V konceptu edukace učitelů založené na výzkumu zdůrazňujeme roli vysokoškolského učitele jako „skladatele“, nebot' tato role může obohatit i jeho roli interpreta.

Ihned se nabízí otázka, zda musí být každý ve vzdělávání učitelů „skladatelem“. Nemusí. Dnes už i u nás dochází k rozdělení vysokoškolských učitelů na akademiky a lektory. Pozice lektora umožňuje do vzdělávání učitelů zapojit odborníky z praxe, zkušené učitele. Nicméně tato personální polarizace s sebou nese určité riziko. Klasifikace zaměstnanců na univerzitách na ty, kteří se orientují na výuku, a na ty, kteří se orientují na výzkum, vede k tomu, že ti první jmenování se cítí jako zaměstnanci „druhé kategorie“ (Barnett, 2005). Barnett (2005) to nazývá mýtem nadřazenosti výzkumníka nad lektora, který je mnohdy implicitně přijímán a ovlivňuje akademické kariéry. Dokazování nadřazenosti či podřazenosti těchto pozic podle našeho názoru není účelné. Jedná se o kvalitativně odlišné pozice, které jsou ale pro současné univerzity a studenty ekvivalentně významné. V pozicích výzkumníka mohou působit akademici, přes pozice lektora pak na univerzity mohou vstupovat odborníci z praxe. 
Přes řadu problémů propojení výzkumu a výuky ve vzdělávání učitelů se identita vysokoškolského učitele a výzkumníka nevylučuje. V budování této identity je také třeba stavět na silných stránkách vysokoškolských učitelů (Robinson \& McMillan, 2006). Podstatné je, aby ti, kteří chtějí výzkum realizovat a postavit na něm svoji výuku, k tomu měli vytvořené podmínky. To je cesta $\mathrm{k}$ tvorbě vysokoškolského kurikula založeného na oblasti expertnosti vysokoškolského učitele, k autonomii vysokoškolských učitelů, skýtající potenciál pro jejich kontinuální profesní růst. Je to také jeden z prvků naplňujících univerzity jako instituce svobodného bádání.

Realitou propojení výuky a výzkumu se empiricky zabývali Šed’ová a kol. (2016), a to ve vztahu k sebepojetí vysokoškolských učitelů. Výzkum realizovali na vzorku 19 začínajících vysokoškolských učitelů na Masarykově univerzitě v Brně. Vysokoškolské učitele na základě získaných dat rozdělili do tří skupin: vědci, učitelé a univerzálové. Právě univerzálové chápou vědu a výuku jako synergicky se podporující aktivity. Jedna role legitimizuje druhou výuka bez opory o vlastní bádání je vnímána jako obsahově prázdná, naopak bádání bez výuky jako samoúčelné. Wiegerová a kol. (2013, s. 66) zjistili, že „začínající výzkumníci chápou výukové činnosti jako snazší než výzkumné, přičemž není rozdíl v tom, zda mají pedagogické vzdělání nebo ne." Autoři to vysvětlují tak, že právě ti, kteří prošli pedagogickým vzděláváním, nehodnotí výuku jako snadnou zřejmě také proto, že u nich byla podporována dovednost sebereflexe. Může to souviset i s věnováním menší pozornosti kvalitě výuky oproti kvalitě vědeckého výstupu na univerzitě.

\section{$5 \quad$ Závěrem aneb „dokud nás smrt nerozdělí"?}

Po představení významu spojení kvalitativního výzkumu a výuky pro studenty a vysokoškolské učitele zbývá třetí pole - tím je samotná pedagogika. Jak říkal Humboldt: „Nikoli učitel je zde pro žáka, ale oba jsou zde pro vědu“ (Šima \& Pabian, 2013, s. 52). Tento pohled si dovolíme rozšířit: Učitel i studenti pracují pro obor, kterým je myšlena jak pedagogická věda, tak i učitelská praxe.

Přestože je dnes pedagogika již etablovanou akademickou disciplínou, musí čelit rostoucím požadavkům na výzkum a výuku (Lopes et al., 2014). Předložili jsme zde kvalitativní výzkum jako cestu k pochopení pedagogických jevů, která oponuje Liessmannovu $(2008$, s. 51) pohledu na vzdělávání v současnosti jako na „rezignaci na snahu vůbec něco chápat“. Právě 
kvalitativní výzkum se jeví jako významný prostředek utváření vědění v pedagogické vědě, jako pojítko výzkumu a výuky na pedagogických fakultách a v neposlední řadě i jako nástroj posílení učitelské profese.

Kvalitativní výzkum je prostředkem, který může dělat z pedagogické fakulty nejen „školu“, ale i univerzitu. Pedagogické fakulty se tak nestanou jen prostředím reprodukce vědění, ale i prostředím jeho produkce, která může probíhat ve spolupráci akademiků, studentů učitelství a učitelů v praxi. Kvalitním výzkumem může pedagogika růst a získávat společenskou relevanci, což ovlivní jak vědní obor, tak i učitelskou praxi.

Učitelství procházelo a prochází procesem profesionalizace, až došlo do fáze, kterou „Hargreaves nazval post-profesionální etapou (s otazníkem). Chtěl tím upozornit na výrazně deprofesionalizační efekt kroků podnikaných vzdělávací politikou, jako např plošného testování, aplikace prvků korporátního sektoru na základě inspirace trhem, uplatňování prvků systému výkonového managementu“ (Píšová et al., 2011, s. 40). Jako jeden z prostředků, kterým lze čelit těmto deprofesionalizačním tlakům, nabízíme edukaci učitelů založenou na výzkumu. Dovednost realizace kvalitativního výzkumu u vysokoškolských učitelů, jejich studentů a u učitelů nesměřuje jen k produkci vědění, ale také k porozumění edukační realitě a vlastní role v ní. Zvažujeme, zda propojení výzkumu a výuky na pedagogických fakultách přispívá k profesionalizaci učitelství a k budování předpokladů expertnosti učitele. Expert pracuje s funkčními abstrahovanými reprezentacemi informací, s tím, co není vidět (typičnost, výjimka, následnost), s reflexí a metakognicí (Píšová et al., 2011). Není právě toto podstatou práce s kvalitativními daty? Není to jedním ze způsobů, kterým se lze vyhnout předávání instantního vědění, a naopak posílit autonomii studentů $\mathrm{v}$ edukační realitě? Mohl by být kvalitativní výzkum odpovědí na Liessmannem (2015) popsanou nevzdělanost např́klad tím, že oproti kompetentnosti bez vědění přinese kompetentnost $k$ vědění? Výzkum $\mathrm{v}$ rukou učitelů by mohl být nárazníkem, který brzdí př́ístupy zvnějšku oslabující jejich expertnost.

Možnosti začlenění kvalitativního výzkumu do vysokoškolské výuky nastiňují cestu k znovuobjevení údajně „ztraceného Humboldtova ráje“. Možná tento text přispívá $\mathrm{k}$ mýtu propojenosti výzkumu a výuky, zároveň se však skrze co nejkonkrétnější rovinu snaží otevřít diskusi na toto téma. Opustili jsme mnohovrstevnatost problému a ukazujeme na možnost propojení kvalitativního výzkumu a výuky, která má dle našeho názoru potenciál přispět 
ke zvýšení profesní autonomie studentů učitelství i vysokoškolských učitelů. A také k životaschopnosti vědy samotné, což je tím hlavním důvodem, proč o jednotě výzkumu a výuky uvažoval právě Humboldt. Kvalitativní výzkum jsme zvolili pro konkrétní ilustraci mostů mezi výzkumem a výukou. Mnohé z toho, co zde zaznělo, platí však pro pedagogický výzkum obecně. Pro studenty učitelství a učitele mohou být stejně užitečné dovednosti vztahující se ke kvantitativnímu či smíšenému designu.

Závěrem nabízíme čtenáři k zamyšlení otázku, zda je spojení výzkumu a výuky „sňatkem z rozumu“, zda je mezi nimi i „hlubší vztah“, a pokud by došlo na „rozvodové řízení“ výzkumu a výuky, co by to pro obě oblasti znamenalo?

\section{Poděkování}

Poděkování patří recenzentům, kteří do uvažování o tématu vnesli mimo jiné metaforu sňatku z rozumu, doc. Tomáši Janíkovi, který si našel čas ke konzultaci první verze textu a doc. Petru Knechtovi, který mě povzbudil k tomu, aby se z původně diskusního př́spěvku ke knize Šimy a Pabiana stala studie.

\section{Literatura}

Barnett, R. (2005). Reshaping the university: New relationships between research, scholarship and teaching. New York: Society for Research into Higher Education/Open University Press.

Biggs, J. B., \& Tang, C. (2011). Teaching for quality learning at university: What the student does. Berkshire: Open University Press.

Boyer commission on educating undergraduates in the research university. (1998). Reinventing undergraduate education: A blueprint for America's research universities. Dostupné z http:// www.niu.edu/engagedlearning/research/pdfs/Boyer_Report.pdf

Bryer, T. A., \& Seigler, D. (2012). Theoretical and instrumental rationales of student empowerment through social and web-based technologies. Journal of Public Affairs Education, 18(3), 429-448.

Cochran-Smith, M. (2005). Teacher educators as researchers: Multiple perspectives. Teaching and Teacher Education, 21(2), 219-225.

Creswell, J. W. (2012). Qualitative inquiry and research design: Choosing among five approaches. Thousand Oaks: Sage.

Dvořáčková, J., Pabian, P., Smith, S., Stöckelová, T., Šima, K., \& Virtová, T. (2014). Politika a každodennost na českých vysokých školách: etnografické pohledy na vzdělávání a výzkum. Praha: Sociologické nakladatelství.

Forest, J. (2002). I prefer to teach: An international comparison of faculty preference for teaching over research. New York: Routledge Falmer.

Froese-Germain, B. (2011). Commentary on the OECD's Programme for International Student Assessment (PISA) 2009 Study. Ottawa: Canadian Teachers' Federation. 
Geschwind, L., \& Broström, A. (2013). Managing the teaching-research nexus: Ideals and practice in research-oriented universities. Higher Education Research \& Development, 34(1), 1-14.

Gratch, A. (2002). Teachers doing qualitative research: Examining school practices. Educational Studies, 33(4), 422-435.

Griffiths, R. (2004). Knowledge production and the research-teaching nexus: The case of the built environment disciplines. Studies in Higher Education, 29(6), 709-726.

Hammersley, M. (1997). Educational research and teaching: A response to David Hargreaves' TTA lecture. British Educational Research Journal, 23(2), 141-161.

Hargreaves, D. (1997). In defence of research for evidence-based teaching: A rejoinder to Martyn Hammersley. British Educational Research Journal, 23(4), 405-419.

Hazzan, O., \& Nutov, L. (2014). Teaching and learning qualitative research $\approx$ Conducting qualitative research. Qualitative Report, 19(24), 1-29.

Healey, M., \& Jenkins, A. (2005). Institutional strategies to link teaching and research. Dostupné z http://www.ipd.gu.se/digitalAssets/1345/1345048_institutional_strategies.pdf

Healey, M., \& Jenkins, A. (2006). Strengthening the teaching research linkage in undergraduate courses and programs. New Directions for Teaching \& Learning, 2006(107), 43-53.

Chetty, R., \& Lubben, F. (2010). The scholarship of research in teacher education in a higher education institution in transition: Issues of identity. Teaching and Teacher Education, 26(4), 813-820.

Janík, T., \& Najvar, P. (2008). Videostudie ve výzkumu vyučování a učení. Orbis scholae, 2(1), $7-28$.

Janíková, M., \& Vlčková, K. (2009). Výzkum výuky: tematické oblasti, výzkumné př́stupy a metody. Brno: Paido.

Jongh, J.-C., Franz, J. M., \& Rhoda, A. J. (2014). Integrating research into teaching and learning: Needs assessment for staff development. African Journal of Health Professions Education, 6(2), 124-128.

Kansanen, P. (1991). Pedagogical thinking: The basic problem of teacher education. European Journal of Education, 26(3), 251-260.

Kansanen, P. (2006). Constructing a research-based program in teacher education. In F. K. Oser (Ed.), Competence oriented teacher training: Old research demands and new pathways, (s. 11-22). Taipei: Sense Publishers.

Kansanen, P. (2011). Selected theses for a sustainable teacher education programme. Orbis Scholae, 5(2), 51-65.

Kansanen, P. (2014). Teaching as a master's level profession in Finland: Theoretical reflections and practical solutions. In O. McNamara, J. Murray, \& M. Jones (Eds.), Workplace learning in teacher education. International practice and policy (s. 279-292). Dordrecht: Springer Netherlands.

Kasper, T. (2007). Německá školská reforma v Československu v letech 1918-1933. Pedagogika, $33(2), 114-131$.

Kincheloe, J., \& Steinberg, S. (Eds.). (2002). Students as researchers: Creating classrooms that matter. Abingdon: Routledge.

Klehr, M. (2012). Qualitative teacher research and the complexity of classroom contexts. Theory Into Practice, 51(2),122-128.

Kotásek, J. (1993). Pedagogický výzkum a transformace vzdělávací soustavy. Pedagogika, 43(4), 363-369. 
Lee, Y. (2014). Promoting teacher autonomy through university-school collaborative action research. Language Teaching Research, 18(2), 222-241.

Liessmann, K. P. (2008). Teorie nevzdělanosti: omyly společnosti vědění. Praha: Academia.

Liessmann, K. P. (2015). Hodina duchů: praxe nevzdělanosti: polemický spis. Praha: Academia.

Lojdová, K. (2015, v tisku). Výzkum interakce studenta učitelství se žáky. In V. Švec, B. Pravdová, \& P. Svojanovský, Determinanty účinnosti učitelských praxí. Brno: Munipress.

Lojdová, K. (2015). Skryté kurikulum, žité příběhy. Narativy studentů učitelství o škole. Pedagogická orientace, 25(5), 649-670.

Lopes, A., Boyd, P., Andrew, N., \& Pereira, F. (2014). The research-teaching nexus in nurse and teacher education: contributions of an ecological approach to academic identities in professional fields. Higher Education, 68(2), 167-183.

Mareš, J. (2009). Edukace založená na důkazech: inspirace pro pedagogický výzkum i školní praxi. Pedagogika, 59(3), 232-258.

McLaren, P., \& Kincheloe, J. (2007). Critical pedagogy: Where are we now? New York: Peter Lang.

Munthe, E., \& Rogne, M. (2015). Research based teacher education. Teaching and Teacher Education, 46, 17-24.

Norton, L. S. (2009). Action research in teaching and learning: A practical guide to conducting pedagogical research in universities. Oxon: Routledge.

Novela zákona o vysokých školách. (2013). Dostupné z http://senat.tul.cz/download/download. php?download=special;novela-zakona-o-vs-katalog-leden-2013.pdf

Pawelleck, A., \& Brendl, S. (2013). Research-based teaching and learning (RBTL) - a paradigm for enhancing teaching and learning at research universities. Revista de Docencia Universitaria, 11(3), 159-172.

Píšová, M., Najvar, P., Janík, T., Hanušová, S., Kostková, K., Janíková, V., \& Zerzová, J. (2011). Teorie a výzkum expertnosti v učitelské profesi. Brno: Masarykova univerzita.

Pol, M., \& Švaříček, R. (2011). Pokus o teorii nepořádku: rozhovor se Stephenem J. Ballem. Studia paedagogica, 16(2), 159-169.

Prudký, L., Pabian, P., \& Šima, K. (2010). České vysoké školství: na cestě od elitního k univerzálnímu vzdělávání 1989-2009. Praha: Grada.

Průcha, J. (1985). Pedagogický výzkum a pedagogická praxe (Aspekt využitelnosti vědeckých informací). Pedagogika, 34(1), 77-90.

Průcha, J. (Ed.). (2009). Pedagogická encyklopedie. Praha: Portál.

Průcha, J., Walterová, E., \& Mareš, J. (2013). Pedagogický slovník. Praha: Portál.

Robinson, M., \& McMillan, W. (2006). Who teaches the teachers? Identity, discourse and policy in teacher education. Teaching and Teacher Education, 22(3), 327-336.

Skalková, J. (1979). Jednota teorie a empirie v pedagogických výzkumech. Pedagogika, 28(5), 467-478.

Spilková, V. (2006). Dilemata v pojetí pedagogické přípravy studentů učitelství. Pedagogika, 56(1), 19-30.

Stöckelová, T. (2012). Nebezpečné známosti: o vztahu sociálních věd a společnosti. Praha: Sociologické nakladatelství.

Šed'ová, K., Švaříček, R., Sedláčková, J., Čejková, I., Šmardová, A., Novotný, P., \& Zounek, J. (2016, v tisku). Pojetí výuky a profesní identita začínajících vysokoškolských učitelů. Studia paedagogica, 21(1). 
Šima, K., \& Pabian, P. (2013). Ztracený Humboldtův ráj: ideologie jednoty výzkumu a výuky ve vysokém školství. Praha: Sociologické nakladatelství.

Štech, S. (2009). Edukace založená na důkazech (Magická víra v pedagogickou účinnost?). In V. Šut'áková \& J. Ferencová (Eds.), Rozvoj a perspektívy pedagogiky a vzdelávania učitelov (s. 160-163). Prešov: Prešovská univerzita.

Štech, S. (2014). Zpochybnění mýtů. In J. Dvořáčková, P. Pabian, S. Smith, T. Stöckelová, \& K. Šima (Eds.), Politika a každodennost na českých vysokých školách: etnografické pohledy na vzdělávání a výzkum (s. 11-15). Praha: Sociologické nakladatelství.

Švaříček, R. (2013). Konec pedagogiky: kritický esej. Studia paedagogica, 18(2-3), 55-72.

Švec, V. (2006). Od znalostí k pedagogické kondici: nový vhled do pedagogické přípravy studentů učitelství? Pedagogika, 56(1), 91-102.

Vlčková, K., Lojdová, K., Lukas, J., Mareš, J., Šalamounová, Z., Kohoutek, T., ... Ježek, S. (2015). Z posluchárny za katedru: mocenské vztahy ve výuce studentů učitelství. Brno: Munipress.

Wiegerová, A., Szimethová, M., Gavora, P., Kalenda, J. Navrátilová, H., \& Kočicová, S. (2013). Začínající výzkumník. Zlín: UTB.

Willcoxson, L., Manning, M. L., Johnston, N., \& Gething, K. (2011). Enhancing the research-teaching nexus: Building teaching-based research from research-based teaching. International Journal of Teaching and Learning in Higher Education, 23(1), 1-10.

\section{Autorka}

Mgr. Kateřina Lojdová, Ph.D., Masarykova univerzita, Pedagogická fakulta, Katedra pedagogiky, Poříčí 31, 60300 Brno, e-mail: lojdova@ped.muni.cz

\section{A rational marriage? Research and teaching in pregradual teacher training on an example of qualitative research}

Abstract: This critical study describes teaching-research nexus in student teachers education on an example of qualitative research. We progressively analyse two discourses: teaching-research nexus at universities including terminology and concepts connected with this nexus, where we discuss duality of teaching and research on examples from Czech and international context. The other discourse concerns the case of qualitative research in teacher training and the benefits of this conjunction for student teachers and for university teachers. The study concludes with a summary of benefits and threats of teaching-research nexus for development of educational science itself, for autonomy of academics and for the teaching profession.

Keywords: qualitative research, research-based teacher education, student teachers, student teachers training, teaching-research nexus 